\title{
PHYSIOCHEMICAL AND MICROBIOLOGICAL QUALITY ASSESSMENT AND DETECTION OF ADULTERANTS OF RAW MILK AVAILABLE IN NAKLA UPAZILA, SHERPUR, BANGLADESH
}

\author{
T. Hasan ${ }^{1}$ and R. H. Rakib ${ }^{* 2}$ \\ ${ }^{1}$ Department of Dairy Science, Bangladesh Agricultural University, Mymensingh-2202 \\ ${ }^{2}$ Goat and Sheep Division, Bangladesh Livestock Research Institute, Savar, Dhaka-1341
}

Fresh milk considered as a complete diet because it contains the essential nutrients as lactose, fat, protein, mineral and vitamins in balanced ratio rather than the other foods (Khalid, 2006). It is defined as the whole, fresh, clean, lacteal secretion obtained by complete milking of one or more healthy animals excluding that obtained within fifteen days before or five days after calving or such periods as may be necessary to render milk practically colostrum free and containing the minimum prescribed percentage of milk fat $(3.5 \%)$ and solids not fat $(8.5 \%)$ (Goff and Hill, 1993). As an essential part of our daily diet, liquid milk plays a crucial role to meet up the increasing nutritional demand as well as ensures food safety in developing countries like Bangladesh. But at the same time, it is highly vulnerable to bacterial contamination and hence is easily perishable (Kim et al., 1983; OECD 2005). Moreover, in Bangladesh, milk adulteration is pretty common. Quality evaluation of milk is thus vital.

In Bangladesh a total of 6.97 million tons of milk were produced over the 2014-2015 fiscal year and about 90 percent of this production comes from cows while the rest is filled by buffaloes and goats (DLS, 2016). The total requirement of milk consumption in our country is 14.6 million tons per year. The demand of milk is growing faster due to rapid increase in population. Therefore, the limited productions of milk lead the dairy personnel to adulterate milk with unhealthy liquor and other solid substances. The way of adulteration is occurred by unhygienic milking, inappropriate transport system, germ favored storage and milk collector itself which creates milk contaminated (Tasci, 2011). For instance, the addition of water to increase volume of milk, thickening agents like starch, flour, skimmed milk powder, whey powder or other ingredients to counter the dilution and extend the solids content of the milk (Fakhar et al., 2006); vegetable oil, sugarcane or urea to compensate the fat, carbohydrate or protein content of diluted milk. Some chemicals such as hydrogen peroxide, carbonates, bicarbonates, antibiotics, caustic soda and even the most lethal chemical formalin to increase the storage period of milk (Tariq,

\footnotetext{
* Corresponding author email: rakib_rezaul@blri.gov.bd
} 
2011), ice to enhance the shelf life of milk; detergents to enhance the cosmetic nature of milk which diminishes foamy appearance and whitening of milk or calcium thioglycolate/ potassium thioglycolate/ calcium salts of thioglycolic acid and urea for whitening of milk and giving it a genuine look (Walker et al., 2004).

The Bangladesh Standards and Testing Institution (BSTI) oblige various chemical and sanitary requirements for the pasteurized milk (BSTI, 2002). However, no standard is known to be established for the raw milk available in Bangladesh. The physiochemical analysis is an important tool to monitor the quality of dairy products. Milk from various mammals are used for producing different dairy products including milk cream, butter, yogurt, ghee, sour milk, etc. (Adam, 2009). The present study was performed to throw out a light on the physiochemical composition and microbiological quality of raw milk that is marketed in Nakla Upazila, Sherpur, Bangladesh and detection of various adulterants of available raw milk.

In this study, individual raw milk samples were collected from different local markets of Nakla upazila, Sherpur, Bangladesh. The selected markets were Narayankhola Bazar, Nakla Bazar and Chandrokona Bazar. Designated by the sample as $\mathrm{A}=$ Narayankhola Bazar, $\mathrm{B}=$ Nakla Bazar, $\mathrm{C}=$ Chandrokona Bazar. Before collection, milk-carrying pots were cleaned and dried properly in order to avoid any kind of external contamination or adulteration. Samples were collected 3 times from 3 different local markets and each time 3 samples were collected. These samples were analyzed at the Dairy Chemistry and Microbiology laboratory of the Department of Dairy Science, Bangladesh Agricultural University, Mymensingh.

Sensory analysis was examined by a panel of experienced judges. The organoleptic properties of milk such as color, flavor and odor, and taste were evaluated with the help of eyes, nose and tongue respectively as per standard score card (ISO, 1995). In this study, several chemical analyses has been done such as percentages (\%) of acidity, fat content, protein content, lactose, ash, total solid (TS), solid not fat (SNF) and specific gravity. Acidity was determined by titrating with N/10 sodium hydroxide solution using the procedure of Aggarwala and Sharma (1961). Fat content was also determined by the Babcock method following the procedure described by Aggarwala and Sharma (1961). Protein percentage was calculated by the formal titration method described by Davide (1997).

The lactose content of milk was estimated by the following formula:

Lactose content of milk $=\%$ SNF $-(\%$ Protein $+\%$ Ash $)$

Ash content of milk samples were determined by the incineration method according to AOAC (2003). SNF and TS were calculated by the following equations:

$\% \mathrm{SNF}=(\mathrm{CLR} / 4)+(\% \mathrm{Fat} / 5)+0.14$

Where, CLR $=$ Corrected Lactometer Reading

Total solids (TS): Total solids $(\mathrm{TS})=\%$ Fat $+\%$ SNF 
Specific gravity test was performed by using Quevenne Lactometer, according to the method described by Aggarwala and Sharma (1961).

Milk is highly perishable because it acts as an enrichment medium for growing and multiplication of the microbial community. The determination of microbial concentration is a crucial step for assuring public health. There are plenty of techniques available for detection of microorganisms. In present study, Total Viable Count and Coliform Count were performed as per recommendation of American Public Health Association (APHA) (1960). In the present study, Clot-onboiling test (COB), Starch test, Formalin test and Alcohol test were performed to determine whether the samples were adulterated by mixing various agents. Data were analyzed statistically by using one way analysis of variance test as per Completely Randomized Design (CRD). For the pair comparison between two treatments DMRT method was used.

Milk samples were brought into the laboratory immediately after collection and then processed. Therefore, samples were ready to determine the physiochemical, microbiological qualities and detection of various adulterants. The results for physical parameters of milk samples obtained from the three places are presented in the (Table 1). There were remarkable differences among the physical parameters like colour, flavour, taste and texture of milk samples obtained from the three different sources. The colours of all the milk samples from different local markets were golden yellowish, yellowish white and whitish. These differences in colour may be due to the differences in nature of feed the cows consumed, the breed, fat and solids contents of the milk. However, due to presence of Carotene (to some extent xanthophylls), milk imparts a yellowish in colour. The result of the present experiment agreed with Amin (2005). It was found that the milk samples collected from Narayankhola, Nakla, Chandrokona local markets of Nakla upazila, Sherpur, Bangladesh were normal in flavour (pleasant aromatic) and texture (free flowing liquid), and slightly sweet in taste. This might be due to the fact that the farmers take hygienic measures during milking and not to allow the cows to eat some sorts of flavoured feed prior to or during milking their cows. These results were agreed with the work of Bari (2001) who showed that the milk flavor and texture was normal (pleasant and aromatic) collected from Bangladesh Agricultural University dairy farm, Mymensingh. 
Table1. Physical parameters of milk samples collected from 3 different local markets of Nakla upazila, Sherpur, Bangladesh

\begin{tabular}{l|c|c|c}
\hline \multirow{2}{*}{ Parameters } & \multicolumn{3}{|c}{ Local markets } \\
\cline { 2 - 4 } & $\mathrm{A}$ & $\mathrm{B}$ & $\mathrm{C}$ \\
\hline Colour & $\begin{array}{c}\text { Golden yellowish=40\% } \\
\text { Yellowish White }=45 \% \\
\text { Whitish }=15 \%\end{array}$ & $\begin{array}{c}\text { Golden yellowish }=50 \% \\
\text { Yellowish White }=35 \% \\
\text { Whitish }=15 \%\end{array}$ & $\begin{array}{c}\text { Golden yellowish }=40 \% \\
\text { Yellowish White }=40 \% \\
\text { Whitish }=20 \%\end{array}$ \\
$\begin{array}{l}\text { Flavou } \\
\mathrm{r}\end{array}$ & $\begin{array}{c}\text { Normal flavour }=100 \% \\
\text { (Pleasant aromatic) }\end{array}$ & $\begin{array}{c}\text { Normal flavour }=100 \% \\
\text { (Pleasant aromatic) }\end{array}$ & $\begin{array}{c}\text { Normal flavour }=100 \% \\
\text { (Pleasant aromatic) }\end{array}$ \\
Taste & Slightly sweet=100\% & Slightly sweet= & Slightly sweet=100\% \\
Textur & Free flowing liquid= & Free flowing liquid= & Free flowing liquid= \\
$\mathrm{e}$ & $100 \%$ & $100 \%$ & $100 \%$ \\
\hline
\end{tabular}

A, Narayankhola Bazar; B, Nakla Bazar; C, Chandrokona Bazar

The acidity of raw milk samples collected from Narayankhola, Nakla, Chandrokona bazar were $0.150 \pm 0.01,0.130 \pm 0.01$ and $0.160 \pm 0.01$ respectively (Table 2). Statistical analysis showed that acidity of milk samples were differed significantly $(\mathrm{p}<0.05)$. The acidity of normal milk sample was within the range of 0.10 to .018 percent with an average of 0.16 percent (Early, 1998). So, the acidity values were within the normal range for the experimental samples. Additionally, the results were in agreement with Bari (2001), who found that the acidity percentage of raw milk of Mymensingh town was $0.141 \pm 0.03 \%$ and also the average acidity percentage of cow milk in Bangladesh Agricultural University Dairy Farm was 0.144 \pm 0.01 . Statistical analysis showed that the average fat content (Table 2) of milk samples collected from different sources were differ significantly $(p<0.05)$. In this experiment highest value of milk-fat was obtained from the milk of Nakla bazar. According to the proposed standard of BSTI-2002 the average fat content of milk is $35 \mathrm{~g} \mathrm{~kg}^{-1}$. Average fat content of milk samples collected from Narayankhola, Nakla and Chandrokona were found to be satisfactory compared to BSTI standard. On the other hand, the result of the present experiment agreed with the report of Asaduzzaman (2000).

The protein content of raw milk samples collected from Narayankhola, Nakla and Chandrokona were insignificant differences among the values (Table 2). The results were agreed with the work of Hossain (2009), who reported that the average values of protein content was $36.65 \mathrm{~g} \mathrm{~kg}^{-1}$ from the dairy farm, BAU, Mymensingh. However, the lactose content (Table 2) of collected milk samples were statistically significant $(\mathrm{p}<0.05)$. Highest value of lactose was obtained from the samples collected from Nakla (46.00 $\mathrm{g} \mathrm{kg}^{-1}$ ) and lowest value obtained from Chandrokona 
(43.33 $\left.\mathrm{g} \mathrm{kg}^{-1}\right)$. Amin (2005) reported that lactose content in milk collected from different sweetmeat shops in Mymensingh town was $38.70 \mathrm{~g} \mathrm{~kg}^{-1}$. The ash content of milk samples collected from Narayankhola, Nakla and Chandrokona were 5.33 \pm 1.15 , $5.67 \pm 0.58$ and $5.33 \pm 0.58 \mathrm{~g} \mathrm{~kg}^{-1}$ respectively (Table 2) and there were insignificant differences among the values. From the experimental result it may be concluded that the ash content of milk sample collected from Nakla bazar was higher than other sources of milk sample. Amin (2005) found average ash content of Mymensingh town was $6.78 \mathrm{~g} \mathrm{~kg}^{-1}$. However, a remarkable difference was found among the total solids contents of milk of different local markets of Nakla Upazilla and statistically they were highly significant $(\mathrm{p}<0.01)$ (Table 2$)$. Islam (2006) studied the milk quality of local cows in BAU dairy farm and found that the total-solids content of cow's milk was $142.50 \mathrm{~g} \mathrm{~kg}^{-1}$. Yadav and Saraswat (1982) also reported that lower total solids content of market milk was within the range of $97.50-115.60 \mathrm{~g} \mathrm{~kg}^{-1}$.

Table 2. Chemical parameters of milk samples collected from 3 different local markets of Nakla upazila, Sherpur, Bangladesh

\begin{tabular}{ccccc}
\hline \multirow{2}{*}{ Parameters } & \multicolumn{3}{c}{ Local markets } & \multirow{2}{*}{ Level of sig. } \\
\cline { 2 - 4 } & $\mathrm{A}$ & $\mathrm{B}$ & $\mathrm{C}$ & $*$ \\
\hline Acidity & $0.150^{\mathrm{a}} \pm 0.01$ & $0.130^{\mathrm{b}} \pm 0.01$ & $0.160^{\mathrm{a}} \pm 0.01$ & $*$ \\
Fat $\left(\mathrm{g} \mathrm{kg}^{-1}\right)$ & $43.67^{\mathrm{ab}} \pm 1.53$ & $46.00^{\mathrm{a}} \pm 1.0$ & $42.00^{\mathrm{b}} \pm 2.0$ & $\mathrm{NS}$ \\
Protein $\left(\mathrm{g} \mathrm{kg}^{-1}\right)$ & $34.67 \pm 1.15$ & $35.67 \pm 1.53$ & $35.67 \pm 1.53$ & $*$ \\
Lactose $\left(\mathrm{g} \mathrm{kg}^{-1}\right)$ & $45.00^{\mathrm{ab}} \pm 1.00$ & $46.00^{\mathrm{a}} \pm 0.00$ & $43.33^{\mathrm{b}} \pm 1.15$ & $\mathrm{NS}$ \\
Ash $\left(\mathrm{g} \mathrm{kg}^{-1}\right)$ & $5.33 \pm 1.15$ & $5.67 \pm 0.58$ & $5.33 \pm 0.58$ & $* *$ \\
TS $\left(\mathrm{g} \mathrm{kg}^{-1}\right)$ & $128.67^{\mathrm{b}} \pm 0.58$ & $133.33^{\mathrm{a}} \pm 1.15$ & $126.33^{\mathrm{c}} \pm 1.53$ & $\mathrm{NS}$ \\
SNF $\left(\mathrm{g} \mathrm{kg}^{-1}\right)$ & $85.00 \pm 1.0$ & $87.33 \pm 2.08$ & $84.33 \pm 2.08$ & $\mathrm{NS}$ \\
Specific gravity & $1.030 \pm 0.00$ & $1.031 \pm 0.00$ & $1.030 \pm 0.00$ & .
\end{tabular}

A, Narayankhola Bazar; B, Nakla Bazar; C, Chandrokona Bazar; Means with different superscripts in the same row differed significantly; $*=$ Significant at $5 \%$ level $(\mathrm{p}<0.05) ; * *=$ Significant at $1 \%$ level $(\mathrm{p}<0.01) ; \mathrm{NS}=$ Non Significant

Solids-not-fat (SNF) content of milk obtained from Narayankhola, Nakla and Chandrokona were insignificant differences among the SNF contents (Table 2). The results were agreed with the work of Islam (2006) who reported that the average SNF percentage of milk of local cows was $87.0 \mathrm{~g} \mathrm{~kg}^{-1}$. On the other hand, statistical analysis also showed that there were no significant differences within the mean specific gravity of samples (Table 2). The result of specific gravity of milk of Nakla 
Bazar (1.031 \pm 0.00$)$ was completely in agreement with Bari (2001), who found the same value of average specific gravity of Cow's milk from BAU Dairy Farm. The result of mean specific gravity indicates that milk of different local markets of Nakla Upazilla was not adulterated, because this could satisfy the normal range of 1.0281.034 (BSTI, 2002).

The total viable count per $\mathrm{ml}$ of different milk samples collected from Narayankhola, Nakla and Chandrokona are presented in table 3. It was observed that there were significant $(\mathrm{P}<0.01)$ differences among the milk samples. The highest total viable count $/ \mathrm{ml}$ was recorded for sample $\mathrm{C}$ which indicates that it contains more favorable condition for growth of microbes may be due to poor hygienic milking and utensils. However the lowest value was recorded for sample A that might be due to maintaining proper hygienic condition. The average values of coliform counts $/ \mathrm{ml}$ of raw milk samples collected from $\mathrm{A}, \mathrm{B}$, and $\mathrm{C}$ were $56.67 \pm 5.77,46.67 \pm 5.77$ and $73.33 \pm 5.77$ per $\mathrm{ml}$ respectively (Table 3 ). Statistical analysis showed that the milk samples were highly significant $(\mathrm{p}<0.01)$ according to the coliform counts/ml of different milk samples and it was observed that the coliform counts/ml of milk samples were moderate. This may be due to poor hygienic milking, improper cleaning of dairy utensils and unhygienic handling during marketing of raw milk.

Table 3. Microbiological parameters of milk samples collected from 3 different local markets of Nakla upazila, Sherpur, Bangladesh

\begin{tabular}{ccccc}
\hline \multirow{2}{*}{ Parameters } & \multicolumn{3}{c}{ Local markets } & Level of sig. \\
\cline { 2 - 3 } & $\mathrm{A}$ & $\mathrm{B}$ & $\mathrm{C}$ & \\
\hline Total viable & & & & \\
count $(\mathrm{CFU} / \mathrm{ml})$ & $111.33^{\mathrm{b}} \times 10^{4}$ & $106.33^{\mathrm{c}} \times 10^{4}$ & $116.66^{\mathrm{a}} \times 10^{4}$ & $*$ \\
& \pm 2.11 & \pm 1.52 & \pm 2.11 & \\
Coliform Count & & & & $* *$ \\
$(\mathrm{CFU} / \mathrm{ml})$ & $56.67^{\mathrm{b}} \pm 5.77$ & $46.67^{\mathrm{b}} \pm 5.77$ & $73.33^{\mathrm{a}} \pm 5.77$ & $*$ \\
\hline
\end{tabular}

A, Narayankhola Bazar; B, Nakla Bazar; C, Chandrokona Bazar; Means with different superscripts in the same row differed significantly; $* *=$ Significant at $1 \%$ level $(\mathrm{p}<0.01) ; \mathrm{CFU}=$ Colony Forming Unit.

The Clot-on-boiling (COB) test of milk samples collected from Naryankhola, Nakla and Chandrokona bazar of Nakla upazila were showed negative result. Bari (2001) showed that all the milk samples collected from BAU Dairy Farm showed negative results on $\mathrm{COB}$ test. Similarly, collected milk samples showed negative results of starch test. Addition of starch increases the SNF content of milk. Apart from the starch, wheat flour, arrowroot, rice flour is also added. Because, it increases the solid content of milk, thereby reducing the amount of fat present in the milk. 
Formalin (40\% Formaldehyde) is poisonous though it can preserve milk for a long time. In case of formalin test, if a violet or blue ring appears at the intersection of the two layers then it shows the presence of formalin. But, formalin test showed the negative result for all collected milk samples from Nakla upazila. In addition, they showed negative results on alcohol test, which was agreed with the report of Bari (2001). Milk sample showed positive results in alcohol test due to bacterial multiplication and enzymatic action in raw milk.

The quality and composition of raw milk depends on its physiochemical parameters that vary from one area to another. Moreover, they are affected by several factors such as type of breeds, forage consumption, feeding schemes, milking incidence, milking process, seasonal changes, lactation period and adulteration. In addition, high level of microbial loads brought about by unhygienic distributions of raw milk also reduces the standard of milk. In the present study, preliminary investigations were carried out to ascertain the physiochemical and microbiological qualities including adulteration parameters of raw milk available in different local markets of Nakla upazila, Sherpur, Bangladesh. All the tested parameters were nearer to normal values of raw milk. These findings may be helpful for the concerned governmental regulatory bodies to monitor the quality of raw milk available in the market. It would be a great interest if further investigations are to be carried out to examine other organic and inorganic components of milk. The study will create awareness among consumers level in urban and rural areas of Bangladesh.

\section{REFERENCES}

Adam, A. A. H. 2009. Milk adulteration by adding water and starch at Khartoum state. Pakistan Journal of Nutrition, 8(4): 439-440

Aggarwala, A. C. and Sharma, R. M. 1961. A Laboratory Manual of Milk Inspection. $4^{\text {th }}$ Ed. Asia Publilishing House, Bombay, India

Amin, M. N. 2005. Studies on the physical and chemical quality of raw milk collected from different sweetmeat shops of Mymensingh town. M. S. Thesis, Department of Dairy Science, Bangladesh Agricultural University, Mymensingh

APHA. 1960. Standard Methods for the Examination of Water and Waste Water, A. E. Eaton, L. S. Clesceri, A. E. Greenberg (Chief ed), American Public Health Association, Maryland, United Book Press Inc

Asaduzzaman.2000. To detect the adulteration of milk obtained from Bangladesh Agricultural University, Mymensingh dairy farm and local markets. M. S. Thesis, Department of Dairy Science, Bangladesh Agricultural University, Mymensingh

Bari, A. K. M. 2001. Comparative study of platform tests on milk in the local markets and Bangladesh Agricultural University dairy farm. M. S. Thesis, Department of Dairy Science, Bangladesh Agricultural University, Mymensingh

BSTI 2002 BDS 1702. 2002. Bangladesh Standard: Specification for Pasteurized Milk. pp. 23, Bangladesh Standards and Testing Institution, Tejgaon Industrial Area, Dhaka 
Davide, C. L.1997. Laboratory guide in dairy chemistry practicals. FAO Regional Dairy Development Centre for Asia and the Pacific. Dairy Training and Research Institute, UPLB, Laguna, Philippines

DLS. 2016. Department of Livestock Services, Ministry of Fisheries and Livestock. Government of the People's Republic of Bangladesh, Dhaka, Bangladesh

Early, R. 1998. The Technology of Dairy Products, $2^{\text {nd }}$ edition. pp. 32-37

Fakhar, H., Law, F. and Walker, G. 2006. The white revolution-dhoodh darya. Pakistan dairy development company. pp.72

Goff, H. D. and Hill, A. R. 1993. Dairy Chemistry and Physics. Chapter1. in: "Dairy Science and Technology Handbook, Vol. 1, Principles and Properties", Y. H. Hui, ed., VCH Publishers, New York. pp. 1-81

Hossain, M. S. 2009. Effect of milk production and milk composition of early lactating cows by supplementation of rice powder with concentrate. M. S. Thesis, Department of Dairy Science, BAU, Mymensingh

Islam, M. R. 2006. Milk yield and quality of different genotype of dairy cows of BAU dairy farm. M.S. Thesis, Department of Dairy Science, BAU, Mymensingh

ISO. 1995.International Organization for Standardization, ISO/TC-34/SC.6, Recommendation of the meeting of the ISO of meat and meat products, The Netherlands, 10-18

Khalid, A. 2006. Milk production in Sudan (conference) Kh Sudan, pp: 1-3

Kim, H., Hardy, J., Novak, G., Ramet, J. P. and Weber, F. 1983. Off-tastes in raw and reconstituted milk, FAO Animal Production and Health Paper 35. Volume 35, p.2, Food \& Agriculture Organization of the United Nations, Rome

OECD. 2005. Dairy policy reform and trade liberalization. Organisation for economic co operation and development, p. 98, OECD Publishing

Tariq, M. A. 2011. Subject: A close look at diatery paterns. http://www.dawn.com/2001/11/05/ebr13.htm

Tasci, F. 2011. Microbiological and chemical properties of raw milk consumed in Burdur, Journal of Animal and Veterinary Advances, 10(5): 635-641

Walker, G. P., Dunshea, F. R. and Doyle, P. T. 2004. Effect of nutrition and management on the Production and composition of milk and protein. Australian Journal of Agriculture, (55): 1009-1028

Yadav, A. N. and Saraswat, B. L. 1982. Note on the physical and chemical qualities of market milk in Varanasi Town. Indian Journal of Research, 1(1) 74-76 